\title{
Attitude Analysis Surrounding Gender-Related Words in Lelaki Harimau
}

\author{
Lalitia Apsari
}

\begin{abstract}
This corpus-based study is a practice of ATTITUDE analysis as an attempt to detect any inclination regarding themes surrounding gender representation in literature. The focus includes gender-related words gadis, perempuan (female), and lelaki (male) in Lelaki Harimau, a fictional novel by Eka Kurniawan. A combination of rule-based computational methods and manual approaches are used to detect and analyse ATTITUDE-conveying terms which may construct gender representation and identity. Initial evaluation shows that references to aesthetic principles and emotion have more interactions with female gender words compared to male gender words. In addition, the equally strong existence of gadis and perempuan for female gender displays interesting characterisations within a gender, suggesting that each word may serve a rather significantly different purpose. This study can be scaled to examine gender representation using notably bigger corpora and is also a preliminary case study in the development of a comprehensive and annotated open dictionary of Indonesian language together with Data Science Indonesia Foundation that is congruent for computational analysis.
\end{abstract}

Index Terms-Appraisal theory, ATTITUDE, corpus linguistics, gender representation.

\section{INTRODUCTION}

How genders are represented in the production and reception of text has been a long and continuous debate, specifically in literary criticism. This study utilised quantitative analysis supported with qualitative detailings to examine words representing genders in Eka Kurniawan's fictional crime novel Lelaki Harimau (international title: Man Tiger). The text is analysed to detect the inclination on how femininity and masculinity are discursively performed in the text, with certain limitations. The study focuses only on 3 gender-related tokens: gadis and perempuan for female gender and lelaki for male gender. This paper does not utilise the characters for the analysis nor impose any generalisation on male and female characters, but rather seeks to determine how those tokens are used, what surrounding words are recognised, and whether there are certain preliminary patterns visible for further studies on femininity and masculinity in literature. Appraisal Theory is used as a basis methodology of detailed analysis to convey potential instances or patterns particularly related to ATTITUDE.

Manuscript received June 15, 2017; revised September 10, 2017.

Lalitia Apsari is with the Descriptive Linguistic Department, Faculty of Cultural Studies, University of Indonesia, Indonesia (e-mail: lalitia.apsari@ui.ac.id).

\section{A. Using Corpora to Analyse Gender}

A corpus can be defined as a systematic collection of naturally occurring texts (of both written and spoken language). Therefore, corpus linguistics is viewed by some as an empirical method of linguistic analysis and description, using real-life examples of language data stored in corpora as the starting point [1], [2]. For many kinds of linguistic analyses, the most important method is to search the corpus in question for the occurrence of certain strings (i.e., words or phrases). As output, the software then usually provides information on the number of these strings occurring in the corpus, on the part of the corpus and/or text in which they were found, and on the (so-called) concordance-lines, which show the strings in question in context. A concordance is 'a collection of the occurrences of a word form, each in its own textual environment' [3], where textual environment equates to the immediate co-text on either side of the search item. It is also called KWIC (Key-Word In Context) analysis. This study uses the KWIC method as a significant initial component of the analysis. It is particularly useful for both hypothesis testing and hypothesis generation, which are the main purposes of the study.

\section{B. Importance of This Study}

The availability of digital linguistic data and other rapidly growing digital sources intended to encourage and prompt research and discussions regarding public, personal, or social issues, has forged demands for development of a quantitative method for analysing people's perspectives, attitudes, and preferences. This study is a practice using Lelaki Harimau, a fiction novel by Eka Kurniawan, which aims to propose a preliminary phase of systematic and replicable linguistic analytical framework to analyse gender representation and identity construction in literature, supported by both quantitative and qualitative methods utilising a combination of systemic functional linguistics framework [4], Appraisal Theory, particularly the ATTITUDE types [5], and the Lövheim cube of emotion [6] to support the AFFECT analysis in the ATTITUDE types.

This study hopes to construe discerning semantic themes surrounding gender-related words gadis, perempuan, and lelaki, which potentially illustrate the author's perspective in defining one type of gender identity in opposition to another. Potential development aims to expand the analysis using bigger corpora to investigate the inclination in theme (beyond gender) surrounding any designated word. This study is also a part of the preliminary phase of case studies in developing a comprehensive and annotated open dictionary of Indonesian language that is compatible and congruent with libraries in any programming languages to 
advance analyses of linguistic data in the Indonesian language. The project is conducted under the Data Science Indonesia Foundation.

\section{METHODOLOGY}

Eka Kurniawan was born on November 28, 1975, and he cites Pramoedya Ananta Toer as one of his favorite writers. The two writers have been compared several times by critics even though the differences of their works are quite noticeable. Kurniawan's works are known to be digressive yet riveting, an ode to Indonesia's oral traditions. His writings contain relatively little dialogue and delve more into the narrative style, where he elaborates upon what the characters do and feel, and thus he is considered to be one of the strongest contemporary storytellers in Indonesia.

\section{A. Material}

The methodology involves the novel Lelaki Harimau [7], a corpus of 42,165 tokens that requires the use of a computerised corpus analysis method, small-scale computational linguistics method, and manual analysis to detect patterns within the linguistic evidence. This corpus has a Type-Token Ratio (TTR) of 0.1264.

To ensure a more focused purpose of this study, not all gender representations are analysed. This study attempts to conduct an initial analysis of gender representation and identities in Lelaki Harimau using 3 selected words: gadis and perempuan for female gender and lelaki for male gender. These gender-related words are selected due to their positions in the top 30 of the sorted word frequency list ${ }^{1}$. Interestingly, Kurniawan doesn't use pria (male) or wanita (female), which are also terms for gender.

Initially, a Term-Document Matrix (TDM) consists of a reference corpus containing 20 Indonesian fictional novels from the year 2000 to 2017 applying Term FrequencyInversed Document Frequency (TF-IDF) weighting is created to analyse how frequently those words appear in the reference corpus, but there are no significant differences between the three words (the TF-IDF value of gadis, perempuan, and lelaki in the reference corpus are 5.57, 7.21, and 4.32 respectively), and they are not significant in the reference corpus as opposed to the specific corpus used to conduct the analysis.

This study uses $\mathrm{R}$ software (version 3.3.3) [8] for the quantitative analyses and visualisations. Association measurements for detecting collocations are based on the likelihood ratio [9] as implemented in the 'quanteda' package [10] in R. The network graph visualisation to illustrate the interaction and networking analysis between the gender-related words and their surrounding words uses Kamada-Kawai’s algorithm [11].

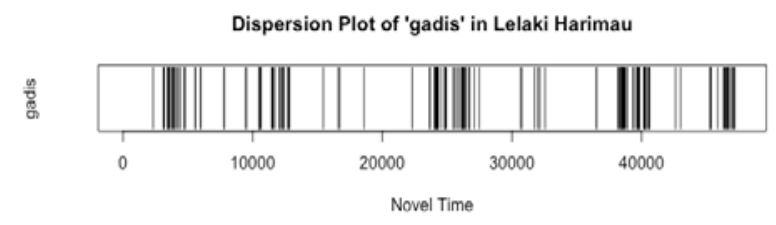

\footnotetext{
${ }^{1}$ A list of stop words in Indonesian is used in the preprocessing phase to exclude determiners, coordinating conjunctions, and prepositions from the word frequency list.
}

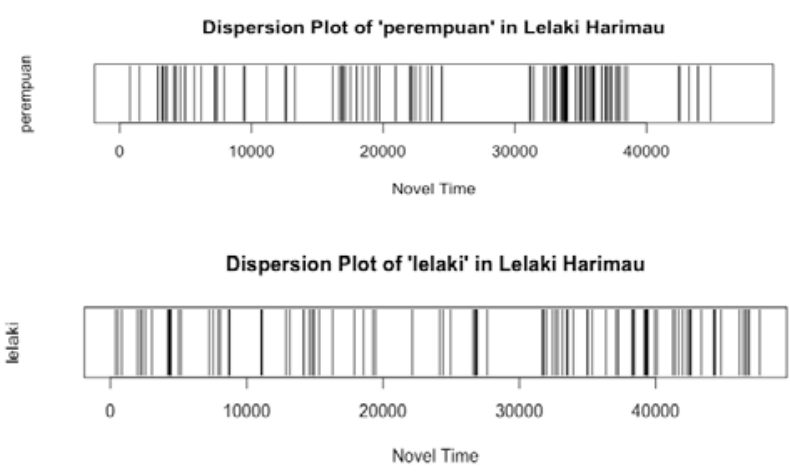

Fig. 1. Dispersion plots of gadis, perempuan, and lelaki in Lelaki Harimau.

The dispersion of gadis, perempuan, and lelaki are different throughout the novel as presented in Fig. 1. There is an evident cluster for gadis in the last chapter and one for perempuan in the fourth chapter, whereas the use of lelaki spreads with an increased frequency towards the last chapter. An interesting pattern is visible in Fig. 2 particularly in the last two chapters, where the usage frequencies of gadis and perempuan in both chapters are in opposition.

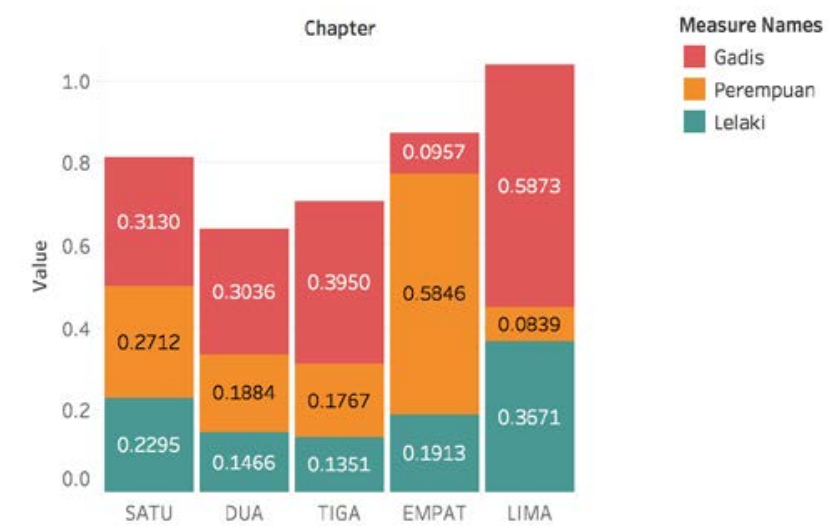

Fig. 2. A scaled proportion of usage frequency between gadis, perempuan, and lelaki throughout all chapters.

Based solely on the last two chapters, an early assumption can be made that gadis and perempuan might be used for different purposes or to construct different identities of female gender. Even though there is no unique pattern found for the male gender, it is still interesting to see how the three words interact with words or phrases around them and what patterns can be assumed from these interactions.

\section{B. Appraisal Theory}

The notion of appraisal was first introduced into psychology by Magna Arnold [12], who defines it as the process through which the significance of a situation for an individual is determined. Appraisal brings about attraction or aversion, and emotion is associated with this "felt tendency toward anything intuitively appraised as good (beneficial), or away from anything intuitively appraised as bad (harmful).” [12]. ATTITUDE types in Appraisal Theory define the specifics of appraisal being expressed: AFFECT (personal emotional state), JUDGEMENT (social or ethical appraisal), and APPRECIATION (evaluation of phenomena).

APPRECIATION typically involves the evaluation of phenomena in relation to appearance or physical traits by reference to aesthetic principles and other systems of social 
value. The attitudinal sub-system of JUDGEMENT encompasses meanings which serve to evaluate human behaviour positively and negatively by reference to a set of institutionalised norms which can be differentiated between personal judgements of admiration or criticism (SOCIAL ESTEEM) and moral judgements of praise or condemnation (SOCIAL SANCTION) [13], [14]. AfFECT is concerned with emotional response and disposition and is typically realised through mental processes of reaction and through attributive relationals of the types. Within this broad scope, the theory is more specifically concerned with the language of evaluation, attitude, and emotion, and with a set of resources which explicitly and interpersonally position a text's proposals and propositions.

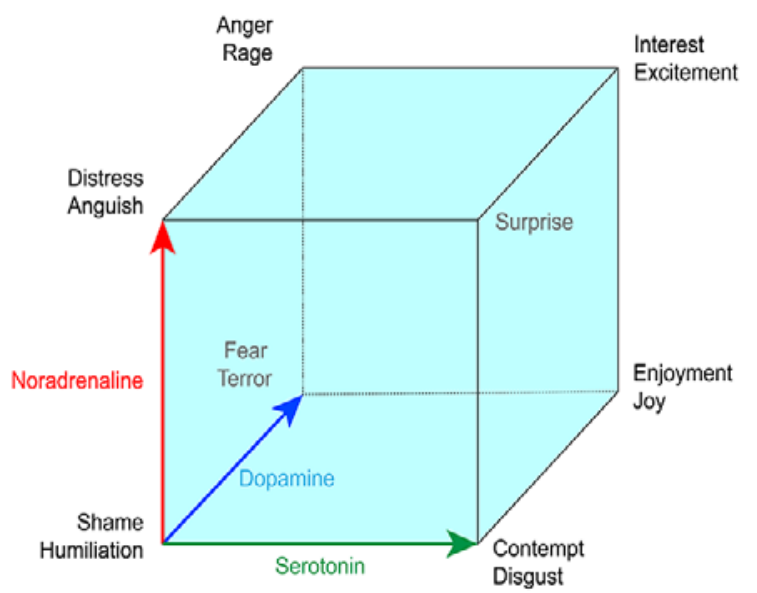

Fig. 3. Lövheim cube of emotion.

For this study, the eight AFFECT categories in the Lövheim cube of emotion in Fig. 3 [6] are together used as a dimensional model of emotion as a grounding base in $b$ uilding a contextual lexicon for attitude analysis. A combination of rule-based computational linguistic approaches and manual labelling are also used to support the categorisation and polarity of a word or phrase based on the sentence [5], [15] and to spot keywords based on commonsense knowledge [16].

\section{ANALYSIS}

In analysing gender, certain words or phrases are usually used to convey femininity and masculinity, which are defined as gendered identities. Expanding from femininity and masculinity, the general characters of a gender are culturally construed and constructed, thus gender definitions are adaptable and malleable concepts. Because these characterisations are not innate, what represents male and female genders might vary socially, culturally, and generationally [17].

\section{A. Concordances and Collocates}

The main challenge of this study is to determine attitudeconveying terms and to continuously build a lexicon from the findings. The terms that construct gender identity description are often characterised by strings of adjectives and nouns [18]. Martin \& White [14] also provided explanations and applications in which other word classes can be used to analyse appraisal of a certain target.
TABLE I: CONCORDANCE SAMPLES OF GADIS IN LELAKI HARIMAU

\begin{tabular}{|c|c|c|c|}
\hline Post & Context (Pre) & Keyword & Context (Post) \\
\hline 2679 & $\begin{array}{r}\text { gambar di film layar } \\
\text { tancap, atau disebabkan }\end{array}$ & gadis & $\begin{array}{l}\text { pujaan }[\text { int }+ \text { ] hati berjalan } \\
\text { dengan lelaki lain. }\end{array}$ \\
\hline 4357 & $\begin{array}{l}\text { mendidih, dan Anwar } \\
\text { Sadat menjawili dagu }\end{array}$ & $\begin{array}{l}\text { gadis- } \\
\text { gadis }\end{array}$ & $\begin{array}{l}\text { berseragam sekolah hingga } \\
\text { mereka merengek [dis-] }\end{array}$ \\
\hline 28165 & $\begin{array}{l}\text { pacar. Tak ada yang lebih } \\
\text { memalukan [hum-] bagi }\end{array}$ & gadis & $\begin{array}{l}\text { di atas dua belas tahun } \\
\text { tanpa dikenal siapa }\end{array}$ \\
\hline 44212 & $\begin{array}{r}\text { lampu penjual kacang } \\
\text { rebus, ia secantik }\left[\mathrm{app}^{+}\right]\end{array}$ & $\begin{array}{l}\text { gadis- } \\
\text { gadis }\end{array}$ & $\begin{array}{l}\text { dekorasi guci Cina, dengan } \\
\text { rambut }\end{array}$ \\
\hline 44333 & $\begin{array}{r}\text { muda perkasa }\left[\mathrm{app}^{+}\right] \\
\text {penakluk babi liar, serasa } \\
\text { ia }\end{array}$ & gadis & $\begin{array}{l}\text { imut } \text { [app+] malu-malu }^{+]} \\
\text {[hum-] . Orang-orang }\end{array}$ \\
\hline 54081 & $\begin{array}{r}\text { itu pun sanggup } \\
\text { menghentikan tangis } \\
\text { [dis-] si }\end{array}$ & gadis & $\begin{array}{l}\text { yang kini menganga } \\
\text { [supø] dengan kata-kata }\end{array}$ \\
\hline
\end{tabular}

TABLE II: CONCORDANCE SAMPLES OF PEREMPUAN IN LELAKI HARIMAU

\begin{tabular}{|c|c|c|c|}
\hline Post & Context (Pre) & Keyword & Context (Post) \\
\hline 14644 & $\begin{array}{r}\text { apa pun sebagaimana } \\
\text { sering ia lakukan saat } \\
\text { melihat }\end{array}$ & $\begin{array}{l}\text { perempuan- } \\
\text { perempuan }\end{array}$ & $\begin{array}{l}\text { cantik } \quad\left[\mathrm{app}^{+}\right] \quad \text { dengan } \\
\text { dandanan provokatif } \text { [prop- } \\
\text { ] macam begitu }\end{array}$ \\
\hline 38361 & $\begin{array}{r}\text { rasa dingin yang beku } \\
\text { sekonyong } \\
\text { mengentakkan si }\end{array}$ & perempuan & $\begin{array}{l}\text { yang tersadar dan } \\
\text { terlonjak [supø]. Segera }\end{array}$ \\
\hline 14667 & $\begin{array}{r}\text { kini sedikit } \\
\text { memejamkan matanya, } \\
\text { diapit seorang }\end{array}$ & perempuan & $\begin{array}{lrr}\text { gembrot } & \text { [app-] } & \text { yang } \\
\text { datang } & \text { bersama } & \text { anak } \\
\text { kecilnya, } & & \\
\end{array}$ \\
\hline 19623 & $\begin{array}{r}\text { bicara dengan kompor } \\
\text { dan panci sebagaimana } \\
\text { biasa. }\end{array}$ & Perempuan & $\begin{array}{l}\text { ini rada sinting [prop-], } \\
\text { paling tidak begitulah pikir }\end{array}$ \\
\hline 43818 & $\begin{array}{r}\text { bangsat } \text { [prop-] } \\
\text { mengetahui ketiadaan } \\
\text { ayahnya, didengar Kasia } \\
\text { membikin }\end{array}$ & perempuan & $\begin{array}{l}\text { itu menghardik [cont-] } \\
\text { untuk tidak membuat kata- } \\
\text { kata }\end{array}$ \\
\hline 19728 & $\begin{array}{c}\text { mengejutkan [supø] itu } \\
\text { bagi Mameh, menyadari }\end{array}$ & perempuan & $\begin{array}{l}\text { ini bisa bersedih [dis-] } \\
\text { pada suami yang sepanjang }\end{array}$ \\
\hline
\end{tabular}

TABLE III: CONCORDANCE SAMPLES OF LELAKI IN LELAKI HARIMAU

\begin{tabular}{|r|r|c|l|}
\hline Post & Context (Pre) & Keyword & Context (Post) \\
\hline 47741 & $\begin{array}{r}\text { Apa pula gunanya } \\
\text { bunga-bunga untuk }\end{array}$ & lelaki & $\begin{array}{l}\text { bangsat [prop-] busuk } \\
\text { [ver-] ini, pikirnya. Namun }\end{array}$ \\
\hline 4844 & $\begin{array}{r}\text { mewariskan wajah } \\
\text { menarik [app+] untuk } \\
\text { mereka. }\end{array}$ & Lelaki & $\begin{array}{l}\text { ini tampan [app+] } \\
\text { selengkapnya, telah }\end{array}$ \\
\hline 37551 & $\begin{array}{r}\text { sana, dan tak ayal ini } \\
\text { kerap bikin }\end{array}$ & lelaki & $\begin{array}{l}\text { itu cemburu [rage-] buta, } \\
\text { menghukum Nuraeni }\end{array}$ \\
\hline 16918 & $\begin{array}{r}\text { keluar dari sarang. } \\
\text { Margio tak bakalan rela }\end{array}$ & lelaki & $\begin{array}{l}\text { tua celaka [prop-] itu } \\
\text { berbuat baik [prop-] untuk }\end{array}$ \\
\hline 57133 & $\begin{array}{r}\text { barangkali ia mewarisi } \\
\text { harimau } \text { keparat [prop-] } \\
\text { itu. }\end{array}$ & Lelaki & $\begin{array}{l}\text { tua ini bertindak bijak } \\
\text { [prop+] untuk tidak }\end{array}$ \\
\hline $\begin{array}{r}\text { membiru, bahkan masih } \\
\text { bisa bersedih [dis-] pada }\end{array}$ & lelaki & $\begin{array}{l}\text { yang jelas tak setia [ver-] } \\
\text { itu. Dan orang }\end{array}$ \\
\hline
\end{tabular}

Neviarouskaya, Prendinger and Ishizuka [19] developed an ATTITUDE lexicon database for ATTITUDE analysis which contains sentiment-conveying adjectives adverbs, nouns, and verbs annotated by sentiment polarity, polarity scores, and weights that was manually extended using attitude labels. The study proposes methods to automatically generate and score a new sentiment lexicon, called SentiFul, and expand it through direct synonymy relations and 
morphologic modifications with known lexical units. However, this is not applicable for the Indonesian language since most of the lexicons that convey sentiment don't have evident modification patterns. Follow-up studies will focus specifically on finding an effective and scalable method to detect sentiment-conveying terms in Indonesian.

Tables I, II, and III show the concordance samples for each word with ATTITUDE labelling based on results from collocations. Here, words and phrases are marked with attitudinal expressions of 'app' for APPRECIATION; 'nor', 'cap', and 'ten' for NORMALITY, CAPACITY, TENACITY respectively in the SOCIAL ESTEEM group; 'ver' and 'prop' for VERACITY and PROPRIETY respectively in the SOCIAL SANCTION group; all of JUDGEMENT [14]; and eight AFFECT categories [6]. '+', ‘-’, and ' $\varnothing$ ' indicate positive, negative, and undecided polarity, respectively.

\section{B. Attitude Analysis (Appraisal Theory)}

\section{1) Appreciation analysis}

A striking disparity is illustrated in Table IV in terms of variation and frequency of attitude-conveying terms between female gender (gadis and perempuan) and male gender (lelaki) with a single occurrence token. No negative sentiment term was found interacting with either gadis or lelaki and there is no interaction between the female gender nodes and male gender node as presented in Fig. 4. The word cantik (beautiful) shares interaction with both gadis (thicker line width indicates more in frequency) and perempuan.

TABLE IV: APPRECIATION ANALYSIS TABLE (CATEGORY AND POLARITY)

\begin{tabular}{|lrl|}
\hline \multicolumn{3}{c}{ gadis } \\
\hline \multicolumn{1}{|c|}{ Word } & Occurrence & Polarity \\
\hline Cantic & 11 & positive \\
Indah & 1 & positive \\
menarik & 1 & positive \\
Imut & 1 & positive \\
Manis & 1 & positive \\
\hline \multicolumn{4}{|c|}{ perempuan } \\
\hline \multicolumn{1}{|c|}{ Word } & 7 & Polarity \\
\hline Cantic & 1 & positive \\
gembrot & 1 & negative \\
semrawut & negative \\
\hline \multicolumn{4}{|c|}{ lelaki } \\
\hline Word & Occurrence \\
\hline tampan & 1 & Polarity \\
\hline \multicolumn{2}{c}{} \\
\hline
\end{tabular}

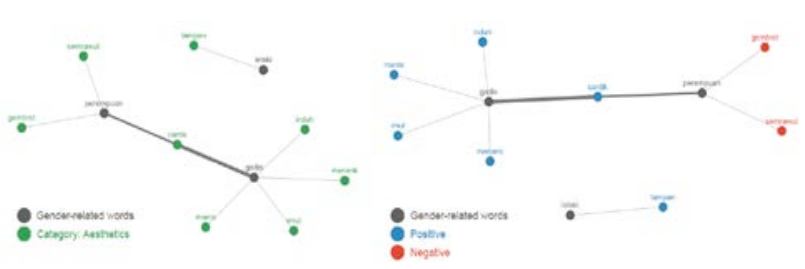

Fig. 4. Network graph of APPRECIATION analysis (category and polarity).

\section{2) Judgement analysis}

It can be seen in Tables V to VII that there is no PROPRIETY praise or condemnation associated with gadis, whereas interactions with perempuan and especially lelaki are quite dominated by it.

Both perempuan and lelaki are surrounded mainly by negative PROPRIETY words in Tables VI and VII. Provided that this is in line with the novel's theme, it is interesting to see the contrast between perempuan and gadis specifically in this aspect.

TABLE V: JUDGEMENT ANALYSIS TABLE OF GADIS (CATEGORY AND POLARITY)

\begin{tabular}{|c|c|c|c|}
\hline \multicolumn{4}{|c|}{ FОLАКIIY) } \\
\hline \multirow{2}{*}{ Category } & \multicolumn{3}{|c|}{ gadis } \\
\hline & Word & Occurrence & Polarity \\
\hline \multirow{4}{*}{ tenacity } & cengeng & 1 & negative \\
\hline & gesit & 1 & positive \\
\hline & cekat & 1 & positive \\
\hline & keberanian & 1 & positive \\
\hline \multirow{3}{*}{ capacity } & cerdas & 1 & positive \\
\hline & ingusan & 1 & negative \\
\hline & (hilang) kewarasan & 1 & negative \\
\hline normality & riang & 2 & positive \\
\hline
\end{tabular}

TABLE VI: JUDGEMENT ANALYSIS TABLE OF PEREMPUAN (CATEGORY AND POLARITY)

\begin{tabular}{|l|lll|}
\hline \multirow{2}{*}{ Category } & \multicolumn{3}{|c|}{ perempuan } \\
\cline { 2 - 4 } & \multicolumn{1}{|c|}{ Word } & Occurrence & Polarity \\
\hline \multirow{3}{*}{ propriety } & baik-baik & 1 & positive \\
& binal & 1 & negative \\
& begundal & 1 & negative \\
& sundal & 1 & negative \\
& genit & 1 & negative \\
\hline \multirow{5}{*}{ tenacity } & cengeng & 1 & negative \\
& pemalas & 1 & negative \\
& bernyali & 1 & positive \\
& sinting & 3 & negative \\
\hline veracity & provokatif & 1 & negative \\
\hline
\end{tabular}

TABLE VII: JUDGEMENT ANALYSIS TABLE OF LELAKI (CATEGORY AND POLARITY)

\begin{tabular}{|c|c|c|c|}
\hline \multirow{2}{*}{ Category } & \multicolumn{3}{|c|}{ lelaki } \\
\hline & Word & Occurrence & Polarity \\
\hline \multirow{10}{*}{ propriety } & baik & 1 & positive \\
\hline & bijak & 1 & positive \\
\hline & keparat & 1 & negative \\
\hline & bangsat & 1 & negative \\
\hline & bengis & 1 & negative \\
\hline & jahil & 1 & negative \\
\hline & mata-keranjang & 1 & negative \\
\hline & keji & 1 & negative \\
\hline & tak kenal adat & 1 & negative \\
\hline & celaka & 1 & negative \\
\hline \multirow{2}{*}{ tenacity } & gagah berani & 1 & positive \\
\hline & bertele-tele & 1 & negative \\
\hline \multirow{2}{*}{ capacity } & cerdas & 1 & positive \\
\hline & cermat & 1 & positive \\
\hline \multirow{3}{*}{ veracity } & busuk & 1 & negative \\
\hline & pendusta & 1 & negative \\
\hline & tak setia & 1 & negative \\
\hline
\end{tabular}

In Fig. 5, only the word cengeng (whiny) is shared between gadis and perempuan, while the word cerdas (smart) is shared between gadis and lelaki.

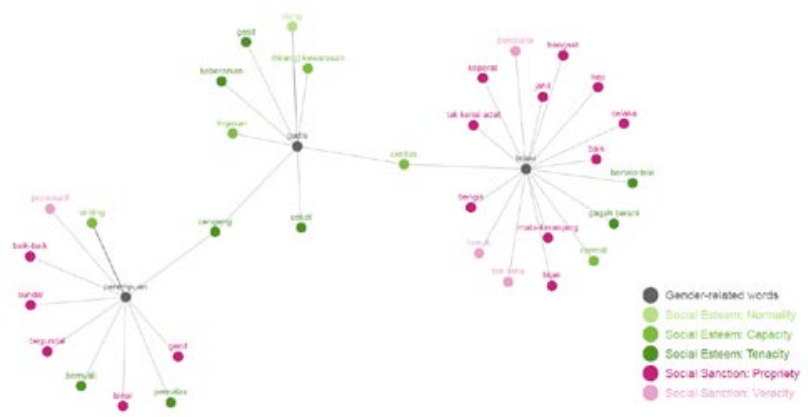

Fig. 5. Network graph of JUDGEMENT analysis (category).

In terms of sentiment, in Fig. 6, gadis displays interaction with an equal ratio, but it is lopsided for both perempuan 
and lelaki with a tendency towards the negative side. It can be inferred from JUDGEMENT analysis that both perempuan and lelaki pose a similar inclination even though the lexicons used for each word are different. For instance, the word binal (wild) is commonly used to describe female characteristics, and is rarely found to describe male characteristics. There is also a clear contrast in inclination between gadis and perempuan or lelaki, particularly in the PROPRIETY aspect.

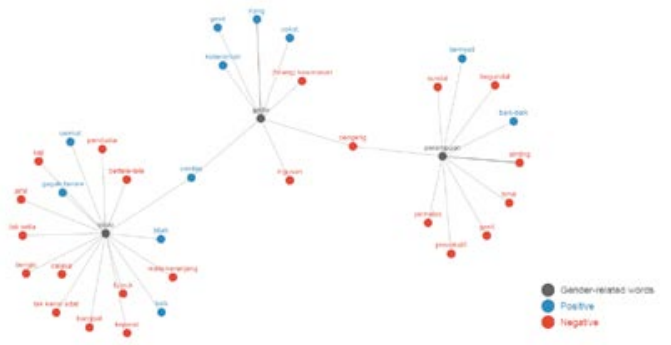

Fig. 6. Network graph of JUDGEMENT analysis (polarity).

\section{3) Affect analysis}

This study uses the Lövheim [6] cube of emotion to construct eight categories of AFFECT. There are many tokens indicating the semantic theme of distress or anguish for gadis and perempuan in Tables VIII and IX. There are tokens found for all eight categories proposed by Lövheim surrounding gadis in Table VIII, as well as two additional tokens, kosong (empty/numb), tak hangat (no warmth/dull), which don't quite fit any of the emotions proposed by Lövheim. Both tokens in English might describe something close to distress or anguish, but in Indonesian they are used to describe having no emotion at all or a completely bland feeling. Arguably, these characteristics evoke different emotions than do distress or anguish; therefore, they should be categorised differently.

TABLE VIII: AFFECT ANALYSIS TABLE OF GADIS (CATEGORY AND POLARITY)

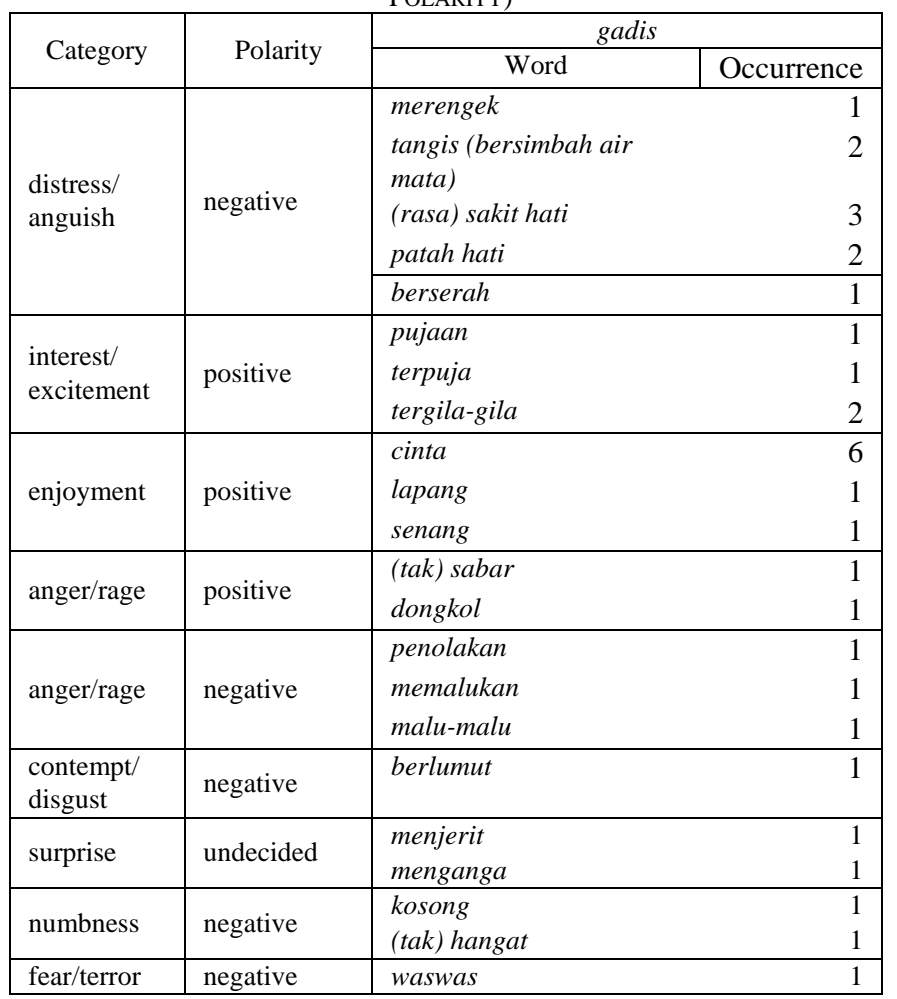

There is also an opposing pattern between gadis and lelaki in terms of interactions with judgement-conveying terms in Tables V and VII and emotion-conveying terms in Tables VIII and X, while perempuan's interactions with the terms in both graphs are quite similar in Tables VI and IX. The word gadis has the most interactions with emotionconveying terms, but the least with judgement-conveying terms, and vice-versa for lelaki.

The words nafsu/berahi (lust/passion) found interacting with perempuan and lelaki in Tables IX and $\mathrm{X}$ relate with excitement; however, the context might vary greatly for this word. Similar to nafsu/berahi (lust/passion), the words terlonjak (jumped), menganga (gawk), and menjerit (scream) can vary on the sentiment scale greatly depending on its pragmatic context. Therefore, an 'undecided' label is assigned for their polarity as displayed in Fig. 8. This label proposes further study in the Appraisal Theory weighting of both categorisation and polarity to provide a more accurate sentiment and theme analysis.

TABLE IX: AfFect ANALysis TABLE of PEREMPUAN (CATEgORY AND POLARITY)

\begin{tabular}{|c|c|c|c|}
\hline \multirow{2}{*}{ Category } & \multirow{2}{*}{ Polarity } & \multicolumn{2}{|c|}{ perempuan } \\
\hline & & Word & Occurrence \\
\hline \multirow{7}{*}{ distress/anguish } & \multirow{7}{*}{ negative } & duka & 3 \\
\hline & & senggukan & 1 \\
\hline & & isak & 1 \\
\hline & & sedih & 3 \\
\hline & & menderitakan & 1 \\
\hline & & menangis & 1 \\
\hline & & membuncah & 1 \\
\hline \multirow{3}{*}{ interest/excitement } & \multirow{3}{*}{ positive } & suka & 1 \\
\hline & & тетија & 1 \\
\hline & & berahi* & 1 \\
\hline \multirow{3}{*}{ enjoyment } & \multirow{3}{*}{ positive } & tertawa & 2 \\
\hline & & senyum & 1 \\
\hline & & terkekeh-kekeh & 1 \\
\hline \multirow{2}{*}{ anger/rage } & \multirow{2}{*}{ negative } & memaki & 1 \\
\hline & & kemarahan & 1 \\
\hline \multirow[t]{2}{*}{ contempt/disgust } & \multirow[t]{2}{*}{ negative } & menghardik & 1 \\
\hline & & membosankan & 1 \\
\hline \multirow[t]{2}{*}{ surprise } & \multirow[t]{2}{*}{ undecided } & menjerit & 1 \\
\hline & & terlonjak & 1 \\
\hline
\end{tabular}

TABLE X: AFFECT ANALYSIS TABLE OF LELAKI (CATEGORY AND POLARITY)

\begin{tabular}{|l|l|l|r|}
\hline \multirow{2}{*}{ Category } & \multirow{2}{*}{ Polarity } & \multicolumn{2}{c|}{ perempuan } \\
\cline { 3 - 4 } & & \multicolumn{1}{|c|}{ Word } & Occurrence \\
\hline distress/anguish & negative & payah & 1 \\
\hline \multirow{2}{*}{ interest/excitement } & \multirow{2}{*}{ positive } & $\begin{array}{l}\text { terpana } \\
\text { nafsu* }\end{array}$ & 1 \\
& & kehangatan & 1 \\
\hline \multirow{2}{*}{ enjoyment } & \multirow{2}{*}{ positive } & senyum & 1 \\
& & ganas & 1 \\
\hline \multirow{2}{*}{ anger/rage } & \multirow{2}{*}{ negative } & cemburu & 1 \\
\hline shame/humiliation & negative & penolakan & 1 \\
& & canggung & 1 \\
\hline contempt/disgust & negative & menyebalkan & 1 \\
\hline
\end{tabular}

The striking difference between female and male gender representation in the AFFECT analysis is the number of words as seen in Table $\mathrm{X}$. Even though this might be due to keeping in line with the theme of Kurniawan's novel, it poses a question of whether this pre-existing stereotypical pattern that the female is considered to be more emotional than the male can also be found across novel genres or even 
across literature in general.

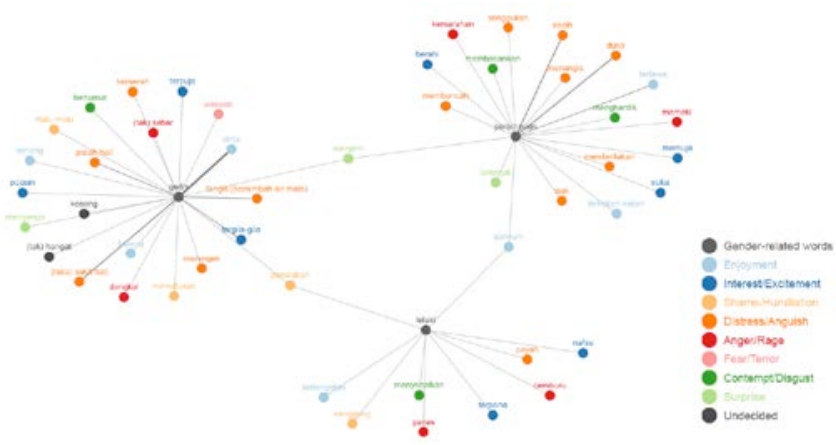

Fig. 7. Network graph of AFFECT analysis (category).

A few words are shared between the keywords, as seen in Fig. 7 and 8. The word penolakan (rejection) is shared between gadis and lelaki, while menjerit (scream) is shared between gadis and perempuan, and senyum (smile) is shared between perempuan and lelaki. In terms of the statement in Fig. 8, there is no singular significant pattern found.

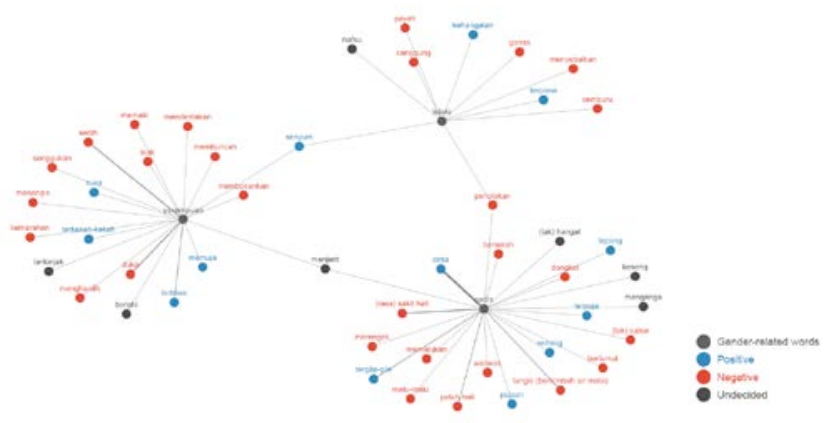

Fig. 8. Network graph of AFFECT analysis (polarity).

\section{CONCLUSION AND FUTURE WORK}

The combination of Appraisal Theory and computational methods employed in this study generate typical and atypical interactions by comparing the syntagmatic and paradigmatic structures, semantics, concordances, and collocates. Eka Kurniawan's style of using vivid and descriptive keywords is an interesting aspect to study in seeking to understand patterns underlying gender representation in literature. Pre-existing stereotypical descriptions of female and male genders are common in the data, such as that of appearance, which are associated more with female gender words and emotion-conveying terms that interact less frequently with male gender words.

The existence of gadis and perempuan as female genderrelated words displays interesting characterisations within a gender. For instance, it can be implied from the data that associating praise and condemnation with gadis is uncommon, while it can be found in many interactions with perempuan. Particularly for the male gender, the sentiment found in its interaction with judgement-conveying terms is distinct in condemnation. Even though there is not much of a disparity between gadis and perempuan in the AFFECT analysis, it would still be interesting to further investigate whether there is a distinguishing theme or style of speech associated with the two words.

The contrasting usage frequency between gadis and perempuan in the last two chapters indicates the different purpose or characterisation by using one or the other. The word gadis usually only differs in usage with perempuan because it describes females who are not yet married. However, the more specific theme difference surrounding the two words has never been discussed with the support of evidence from quantitative analyses. To conduct a thorough and general gender analysis in the literature, every genderrelated aspect need to be considered and analysed. This study also shows how the scoring and weighting system of Appraisal Theory elements for both categorisation and polarity is paramount, because each word imposes complex meanings that might overlap in category or polarity to different degrees. Further analysis might provide not just potential instances or patterns generated from word interactions, but also overall accurate identity categorisation and profiling.

Early experiments to quantify ATTITUDE analysis focusing on distinct ATTITUDE types were conducted by Taboada and Grieve [20]. Taboada and Grieve determined a potential value of adjectives for APPRECIATION, JUDGEMENT, and AFFECT by calculating the PMI with the pronoun-copular pairs such as 'I was (affect)', 'he/she was (judgement)', and 'it was (appreciation)'. Whitelaw et al. [21] also used a machine learning approach with fine-grained semantic distinctions in attitude types and orientation, utilising a 'bag of words' to classify movie reviews. However, these endeavours are mainly designed for English language usage. A robust and comprehensive dictionary in Indonesian with word classes, POS rules, and scoring and weighting system will be a great contribution to support contextual and more accurate research in linguistics, with the aim to provide natural language understanding for machine learning and artificial intelligence purposes' contextual analysis of language in Indonesia.

\section{REFERENCES}

[1] C. David, An Encyclopedic Dictionary of Language and Languages, Oxford, UK: Blackwell. Print, 1992.

[2] J. Howard, Key Terms in Linguistics, London: Continuum. Print, 2007.

[3] S. J. McHardy, Trust the Text: Language, Corpus and Discourse. London: Routledge. Print, 2005.

[4] M. A. K. Halliday, An introduction to Functional Grammar, London: Edward Arnold, 1994.

[5] M. Karo and S. Pulman, "Sentiment composition," in Proc. Natural Language Processing International Conference on the Recent Advances, pp. 378-382, 2007.

[6] L. Hugo, "A new three-dimensional model for emotions and monoamine neurotransmitters,” Medical Hypotheses, vol. 78, no. 2, pp. 341-48, 2011.

[7] K. Eka, Lelaki Harimau. Jakarta: Gramedia Pustaka Utama, 2004.

[8] R. C. Team. (2017). R: A language and environment for statistical computing. $R$ Foundation for Statistical Computing, Vienna, Austria. [Online]. Available: https://www.R-project.org/

[9] M. Chris and H. Schütze, Foundations of Statistical Natural Language Processing, Cambridge, MA: MIT Press, 1999.

[10] B. Kenneth and P. Nulty. (2017). Quanteda: Quantitative analysis of textual data. $\mathrm{R}$ package version: 0.9.9-24. [Online]. Available: https://github.com/kbenoit/quanteda

[11] T. Kamada and S. Kawai, "An algorithm for drawing general undirected graphs,” Information Processing Letters, 1989.

[12] A. Magda, Emotion and Personality, New York: Columbia University Press, 1960.

[13] I. Rick, S. Feez, and P. R. R. White, Media Literacy, Sydney, Disadvantaged Schools Program, NSW Department of School Education, 1994.

[14] J. R. Martin and P. R. R. White, The Language of Evaluation: Appraisal in English, Palgrave, London, UK, 2005. 
[15] V. S. Subrahmanian and D. Reforgiato, "AVA: Adjective-verbadverb combinations for sentiment analysis," Intelligent Systems, IEEE, vol. 23, no. 4, pp. 43-50, 2008.

[16] H. Liu, H. Lieberman, and T. Selker, "A model of textual affect sensing using real-world knowledge," in Proc. IUI-2003, pp. 125-132, 2003.

[17] P. Baker, "No Effeminates Please: A Corpus-based analysis of masculinity via personal adverts in gay news/times 1973-2000," in Masculinity and Men's Lifestyle Magazines, B. Benwell, Ed. Blackwell. Oxford, 2003.

[18] P. Bruthiaux, Me Tarzan, You Jane: Linguistic Simplification in "Personal Ads" Register, In Biber and Finegan (1994a), 136-54, 1994.

[19] A. Neviarouskaya, P. Helmut, and M. Ishizuka, "SentiFul: Generating a reliable lexicon for sentiment analysis," in Proc. the International Conference on Affective Computing and Intelligent Interaction, IEEE, Amsterdam, Netherlands, 2009, pp. 363-368.

[20] M. Taboada and J. Grieve, "Analyzing appraisal automatically,” in Proc. AAAI Spring Symposium on Exploring Attitude and Affect in Text, pp.158-161, 2004.

[21] C. Whitelaw, N. Garg, and S. Argamon, "Using appraisal groups for sentiment analysis," in Proc. the 14th ACM International Conference on Information and Knowledge Management, CIKM, Bremen, Germany, pp. 625-631, 2005.

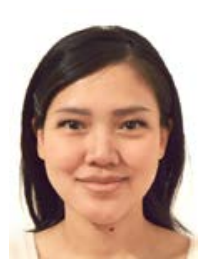

Lalitia Apsari was born in Jakarta, Indonesia. She received her bachelor of architecture (B.Arch) degree in 2006 from University of Indonesia with an undergraduate thesis on philosophy and semiotic studies on Prambanan Temple's iconography using phenomenology as the main analysis approach.

She attended the Digital Humanities at Oxford Summer School (DHOxSS) focusing on Data Science for the Humanities. She also participated in a wide range of courses such as "Visualizing Japan (1850s-1930s): Westernization, Protest, Modernity", a collaboration between HarvardX and MITx, and "The science of everyday thinking" by University of Queensland. She has been a co-curator for TEDxJakarta since 2010, an advocate of digital humanities movement in Indonesia, and a member of data science Indonesia community. Her multidisciplinary research interests include phenomenology and deconstruction, cognition and appraisal theory, the computation of meaning from corpora, and digital humanities.

Mrs. Lalitia Apsari is currently pursuing her graduate study in Linguistics at University of Indonesia while being an assistant researcher to develop comprehensive and contextual language resources for humanities studies in Indonesia. She is also completing her research on the manifestation and change of human cognition as reflected in a large text corpora of newspaper articles in Indonesia collected since 2004. 